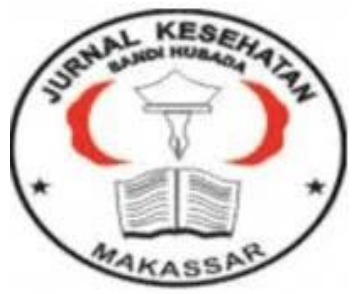

\author{
Jurnal Ilmiah Kesehatan Sandi Husada \\ hhttps://akper-sandikarsa.e-journal.id/JIKSH \\ Volume 9 Nomor 2 Desember 2020, pp 1111-1116 \\ p-ISSN: 2354-6093 dan e-ISSN: 2654-4563 \\ DOI: $10.35816 /$ jiskh.v10i2.483
}

\title{
Insomnia Selama Pandemi COVID-19
}

Artikel Review

Insomnia During COVID-19 Pandemic

\section{Devi Yulia Putri Haryanti}

Pendidikan Dokter, Fakultas Kedokteran, Universitas Lampung

\section{Artikel info}

Artikel history:

Received; Sepetember 2020

Revised: Oktober 2020

Accepted; November 2020

\begin{abstract}
Abstrak
COVID-19 merupakan penyakit baru yang sudah menjadi pandemi global. Penyebaran yang sangat cepat di seluruh dunia dan berbagai manifestasi klinik yang ada membuat masyarakat takut terinfeksi SARS-CoV-2. Hal ini dapat berpengaruh terhadap kualitas dan pola tidur masyarakat yang menimbulkan terjadinya insomnia. Tujuan dari artikel ini untuk mengetahui dampak COVID-19 terhadap kejadian insomnia di masyarakat. Metode yang digunakan yaitu systematic literatur review. Hasil dari literature review ini adalah pandemi COVID-19 berdampak terhadap kejadian insomnia di masyarakat serta memperburuk gejala pasien yang sudah terdiagnosis insomnia. Hal ini terjadi karena ketakutan masyarakat terhadap penyakit COVID-19. Selain itu, terjadi banyak perubahan terhadap rutinitas seharihari masyarakat selama pandemi COVID-19 yang berpengaruh terhadap kejadian insomnia.
\end{abstract}

\begin{abstract}
.
COVID-19 is a new disease that has become a global pandemic. The spread that is very fast around the world and various manifestations clinics make people afraid of infection SARS-CoV2. This can affect the quality and sleep patterns of people, which can lead to insomnia. The purpose of this article is to determine the impact of COVID-19 on the incidence of insomnia in society. The method used is a systematic literature review. The result of this literature review is that the COVID-19 pandemic has an impact on the incidence of insomnia in the community and worsens the symptoms of patients who have been diagnosed with insomnia. This happened because of people's fear of COVID-19 disease. Besides, there have been many changes to people's daily routines during the COVID-19 pandemic which have affected the incidence of insomnia.
\end{abstract}

Keywords:

Insomnia;

Pandemi;

COVID-19;
Coresponden author: Email: devi.yulia31@gmail.com 


\section{Pendahuluan}

Pada bulan Desember 2020, terdapat penemuan virus baru di Wuhan, Tiongkok yang membuat khawatir banyak orang. Virus tersebut adalah SARS-CoV-2. Severe acute respiratory syndrome coronavirus 2 (SARS-CoV-2) dapat menyebabkan coronavirus disease 2019 (COVID-19) (WHO,2020). COVID-19 telah dinyatakan sebagai pandemi oleh World Health Organization karena tingginya penyebaran dan tingkat penularan. COVID-19 pada manusia dapat menyebabkan infeksi saluran pernapasan dan pencernaan (Liu et al., 2020). Pada tanggal 30 Oktober 2020, terhitung 44.888 .869 kasus terkonfirmasi dan 1.178.475 angka kejadian kematian akibat COVID-19 diseluruh dunia, 9.138. 338 kasus terkonfirmasi di Asia Tenggara, serta di Indonesia 404.048 kasus terkonfirmasi dengan 3565 kasus terbaru dalam 24 jam terakhir dan 13.701 angka kejadian kematian kumulatif di indonesia (WHO, 2020).

Dalam penelitian yang dilakukan oleh Wang et al tahun 2020 pada 138 pasien rawat inap terkonfirmasi COVID-19, manifestasi klinik yang paling umum dialami pasien saat onset penyakit, yaitu demam (98,6\%), kelelahan (69,6\%), batuk kering $(59,4 \%)$, mialgia $(34,8 \%)$, dispnea $(31,2 \%)$ dan gejala lainnya seperti ekspektorasi, sakit tenggorokan, sakit kepala, pusing, diare, mual, muntah serta nyeri perut. Beberapa komplikasi yang terjadi, yaitu syok $(8,7 \%)$, penyakit jantung akut $(7,2 \%)$, artimia $(16,7 \%)$, sindrom gangguan pernapasan akut (ARDS) $(19,6 \%)$, dan penyakit ginjal akut $(3,6 \%)$. Hasil pemindaian CT toraks yang dilakukan pada semua pasien menunjukkan adanya ground glass opacity (GGO) (Wang et al., 2020). Penyebaran SARS-CoV-2 bisa melalui dua cara. Pertama secara langsung dengan penularan dari manusia ke manusia melalui percikan ludah ketika pasien batuk, bersin atau berbicara pada jarak kurang dari enam kaki (hampir dua meter). Kedua secara tidak langsung dengan penularan melalui udara dan benda yang terkontaminasi jika seseorang menyentuh permukaan yang terkontaminasi dengan SARS-CoV-2 kemudian tangan bersentuhan langsung dengan selaput lendir seperti mata, hidung, atau mulut (Lotfi et al., 2020).

Dalam studi yang dilakukan oleh Voitsidis et al (2020), kekhawatiran masyarakat terkait pandemi COVID-19 menyebabkan banyaknya kejadian insomnia pada populasi di Yunani. Menurut Morin \& Carrier (2020), pandemi COVID-19 telah berdampak besar pada kualitas tidur yang dapat menyebabkan insomnia akut pada beberapa orang dan memperburuk gejala pada mereka yang sudah mengalami insomnia. Tujuan dilakukannya penelitian systematic literature review ini untuk mengetahui dampak pandemi COVID-19 terhadap kejadian insomnia di masyarakat.

\section{Metode}

Metode dilakukan dengan literature review dari berbagai artikel internasional dan website yang ditelusuri melalui situs NCBI, Google Scholar, Elsevier dan website WHO dengan menggunakan kata kunci yang relevan. Kata kunci yang digunakan adalah insomnia, pandemi dan COVID-19. Sebanyak 17 artikel yang diterbitkan pada tahun 2016-2020 dianalisis dengan menggunakan metode systematic literature review.

\section{Hasil Dan Pembahasan}

Penelitian Voitsidis et al tahun 2020 menyatakan hasil sebanyak 37,6\% dari 2472 orang sampel di Yunani mendapatkan masalah insomnia selama pandemi COVID-19 terutama terjadi pada wanita dan masyarakat yang tinggal di perkotaan (Voitsidis et al., 2020). Penelitian lain oleh Marelli et al tahun 2020 menunjukkan peningkatan prevalensi insomnia sebelum dan selama lockdown akibat pandemi COVID-19 menggunakan 
kuesioner Pittsburgh Sleep Quality Index (PSQI), Insomnia Severity Index (ISI) dan Morningness-Eveningness Questionnaire (MEQ). Penelitian yang dilakukan terhadap 400 peserta yang terdiri dari 307 mahasiswa dan 93 pekerja, didapatkan prevalensi insomnia sebelum pandemi COVID-19 sebesar 24\% menjadi 40\% selama pandemi COVID-19. Selain itu, terjadi peningkatan kesulitan inisiasi tidur pada pekerja dari $15 \%$ menjadi $42 \%$. Lockdown selama pandemi COVID-19 lebih berdampak pada mahasiswa daripada pekerja dan wanita daripada laki-laki (Marelli et al., 2020). Penelitian Wang et al tahun 2020 menyatakan bahwa perempuan dan pelajar menderita dampak psikologis yang lebih besar dari pandemi COVID-19.

Shi et al tahun 2020 melakukan penelitian terhadap 56.679 orang di China dengan usia 18-39 tahun sebanyak 69,6\% yang mengalami insomnia selama pandemi COVID-19. Penelitiannya mendapatkan hasil sebanyak 29,2\% dari populasi atau 16.564 total orang mengalami insomnia dengan rincian sebanyak 23,5\% atau 13.308 orang mengalami subthreshold insomnia dan 5,7\% atau 3256 orang mengalami insomnia sedang sampai berat. Responden yang mengalami insomnia dari total populasi adalah mereka yang dikonfirmasi atau dicurigai COVID-19, memiliki keluarga atau teman dengan COVID-19 yang dikonfirmasi atau dicurigai, pekerjaan dengan risiko tinggi terkena paparan COVID19, penduduk yang tinggal di Provinsi Hubei, penduduk yang pernah ke Provinsi Hubei selama dua bulan terakhir, melakukan kontak dengan pasien COVID-19, menjalani karantina, belum kembali bekerja, pekerja garda terdepan dan memiliki keluarga atau teman yang bekerja sebagai garda terdepan. Responden yang dikonfirmasi atau dicurigai COVID-19 memiliki kemungkinan dua sampai tiga kali lebih besar mengalami insomnia daripada yang lain (Shi et al., 2020).

Penelitian Lin et al tahun 2020 menyatakkan bahwa terdapat 20,05\% dari 5641 responden yang mengalami insomnia selama pandemi COVID-19. Penelitian yang dilakukan terhadap empat kelompok responden berdasarkan tingkat ancaman terkena COVID-19, yaitu kelompok satu adalah pasien rawat jalan yang terkonfirmasi COVID-19; kelompok 2 adalah pasien yang berkunjung ke rumah sakit karena demam; kelompok tiga adalah orang yang terkait dengan kelompok satu dan dua seperti teman, kerabat serta keluarga; kelompok empat adalah masyarakat umum yang memeroleh informasi mengenai COVID-19 menunjukkan bahwa insomnia paling tinggi terjadi pada perempuan, usia muda, tinggal di wilayah episentrum dan mengalami tingkat ancaman tinggi COVID19. Sebanyak 20,01\% responden menghabiskan waktu lebih dari satu jam berdiam diri di tempat tidur terutama kelompok dua dan empat menghabiskan waktu lebih lama karena tidak pergi bekerja dan tinggal di rumah (Lin et al., 2020).

Pandemi COVID 19 sangat erat kaitannya dengan kejadian insomnia. Dalam sebuah penelitian yang dilakukan terdapat 24,66\% responden mengalami insomnia dari 1172 responden yang di diagnosis gangguan psikotik akibat pengaruh pandemi COVID-19 (Huang et al., 2020). Pandemi COVID -19 juga memperburuk gejala dari pasien yang sudah terdiagnosa insomnia Dalam penelitian Yang et al (2020), menilai status tidur 738 pasien dengan diagnosa insomnia kronis menggunakan Pittsburgh Sleep Quality Index (PSQI) menghasilkan skor rata-rata 11,28, jauh lebih tinggi dari skor maksimum setelah 8 minggu follow-up menyatakan bahwa secara statistik ada perbedaan yang signifikan pada kualitas tidur yang buruk selama pandemi COVID-19.

Kondisi pandemi COVID-19 cenderung memberi dampak negatif dalam beberapa faktor yang memengaruhi kualitas tidur seseorang karena banyak perubahan yang terjadi dalam rutinitas sehari-hari, hidup dalam ketidakpastian, rasa takut akan kesehatan, rasa khawatir akan situasi dan durasi pandemi yang berkepanjangan, kehilangan pekerjaan, isolasi mandiri di rumah, hilangnya tempat hiburan dan berkurangnya interaksi sosial antar individu (Altena et al., 2020). Kualitas tidur yang buruk dapat berdampak pada 
kesehatan dan kehidupan pribadi. Hal ini dapat menyebabkan berkurangnya kinerja dalam kegiatan sehari-hari seperti sekolah dan bekerja, meningkatkan risiko kecelakaan dalam berkendara, memperburuk kondisi medis dan kejiwaan serta menurunkan kualitas hidup (Mollayeva et al., 2016).

Menurut Morin \& Carrier (2020), pandemi COVID-19 berpengaruh besar terhadap kualitas tidur individu juga menyebabkan insomnia akut pada beberapa orang atau bahkan memperburuk gejala pada mereka yang sudah menderita insomnia. Perubahan-perubahan yang terjadi mengenai tekanan pekerjaan, keuangan, kewajiban terhadap keluarga, interaksi sosial dan kesehatan dapat mengganggu kualitas tidur dan ritme sirkadian individu. Selain itu, aktivitas individu diawali bangun tidur di pagi hari, bekerja, berinteraksi sosial dengan individu lain, berekreasi dan tidur di malam hari mulai mengalami perubahan yang memengaruhi ritme biologis individu semenjak pandemi COVID-19 dimana setiap individu juga melakukan karantina di rumah. Karantina di rumah juga memengaruhi aktivitas olahraga dan kebiasaan makan, banyak yang lebih memilih tidur siang, menonton televisi, dan bermain handphone di tempat tidur, serta berkurangnya paparan sinar matahari yang memengaruhi ritme biologis (Morin \& Carrier, 2020).

Selama pandemi COVID-19 banyak negara melakukan lockdown yang mengakibatkan perubahan gaya hidup dan dan hubungan sosial sehingga hal ini meningkatkan kecemasan masyarakat terhadap ketakutan terinfeksi (Bao et al., 2020). Cemas, stres dan depresi dapat menyebabkan terganggunya pola tidur, meningkatkan angka kejadian insomnia, meningkatkan kekambuhan gejala insomnia, memburuknya frekuensi terjaga selama tidur, bangun yang lebih awal dan bahkan mimpi buruk atau gangguan tidur lainnya (Sinha, 2016). Menurut Yang et al (2020), pandemi COVID-19 memperburuk gejala pasien dengan insomnia kronis dalam hal kualitas tidur, latensi tidur, durasi tidur, gangguan tidur, efisiensi tidur dan fungsi di siang hari. Hal ini terjadi karenya sulitnya membatasi waktu istirahat dan waktu kerja selama masa isolasi di rumah sehingga sulit untuk tertidur saat harus tidur yang berpengaruh buruk terhadap latensi tidur, kontuinitas tidur dan kualitas tidur. Pasien kurang tidur di malam hari dan aktivitas di siang hari terganggu (Yang et al., 2020).

Seiring dengan berkembangnya upaya pencegahan dan pengobatan dalam menangani pandemi COVID-19, masyarakat juga telah mengembangkan kebiasaan tidur yang buruk akibat pandemi COVID-19 yang perlu mendapat perhatian (Lin et al., 2020). Perlu dilakukannya sosialisasi mengenai intervensi perilaku kebiasaan tidur yang sehat (sleep hygiene) kepada masyarakat. Sosialisasi akan pentingnya karantina di rumah tetapi tetap berolahraga di dalam ruangan, membuka jendela dan ventilasi ruangan, memastikan keteraparan sinar matahari yang cukup dapat ditempuh dengan telemedicine agar memberi manfaat bagi masyarakat dengan insomnia dan gangguan tidur lainnya selama pandemi COVID-19 (Morin \& Carrier, 2020). Beberapa hal dapat dilakukan untuk mengurangi gejala insomnia selama pandemi COVID-19 adalah menerapkan pola tidur yang sehat, pembatasan waktu tidur, terapi perilaku kognitif lainnya dan dikombinasikan dengan metode yang lebih luas (Yang et al., 2020).

\section{Simpulan Dan Saran}

Pandemi COVID-19 tidak hanya berdampak terhadap kesehatan fisik saja, tetapi juga berdampak terhadap kesehatan mental juga akan mempengaruhi kualitas tidur masyarakat bahkan sampai menyebabkan insomnia atau memperburuk gejala insomnia yang sudah ada. ketakutan dan kecemasan akan terinfeksi SARS-CoV-2 yang berkepanjangan memengaruhi kualitas tidur dan waktu tidur masyarakat. Selain itu, 
isolasi di rumah selama pandemi COVID-19 mengubah rutinitas masyarakat sehari-hari. Ketidakteraturan jadwal beraktivitas dan istirahat akan memengaruhi ritme sirkadian masyarakat. Oleh karena itu, perlu adanya intervensi untuk mencegah kejadian insomnia serta mengurangi gejala insomnia pada masyarakat selama pandemi COVID-19.

\section{Daftar Rujukan}

Altena, E., Baglioni, C., Espie, C., Ellis, J., Gavriloff, D., \& Holzinger, B. et al. (2020). Dealing with sleep problems during home confinement due to the COVID-19 outbreak: Practical recommendations from a task force of the European CBT-I Academy. Journal Of Sleep Research, 29(4). https://doi.org/10.1111/jsr.13052

Bao, Y., Sun, Y., Meng, S., Shi, J., \& Lu, L. (2020). 2019-nCoV epidemic: address mental health care to empower society. The Lancet, 395(10224), e37-e38. https://doi.org/10.1016/s0140-6736(20)30309-3

Huang, Y., Wang, Y., Zeng, L., Yang, J., Song, X., \& Rao, W. et al. (2020). Prevalence and Correlation of Anxiety, Insomnia and Somatic Symptoms in a Chinese Population During the COVID-19 Epidemic. Frontiers In Psychiatry, 11.। https://doi.org/10.3389/fpsyt.2020.568329

Lin, L., Wang, J., Ou-yang, X., Miao, Q., Chen, R., \& Liang, F. et al. (2020). The immediate impact of the 2019 novel coronavirus (COVID-19) outbreak on subjective sleep status. Sleep Medicine. https://doi.org/10.1016/j.sleep.2020.05.018

Liu, J., Zheng, X., Tong, Q., Li, W., Wang, B., \& Sutter, K. et al. (2020). Overlapping and discrete aspects of the pathology and pathogenesis of the emerging human pathogenic coronaviruses SARS-CoV, MERS-CoV, and 2019-nCoV. Journal Of Medical Virology, 92(5), 491-494. https://doi.org/10.1002/jmv.25709

Lotfi, M., Hamblin, M., \& Rezaei, N. (2020). COVID-19: Transmission, prevention, and potential therapeutic opportunities. Clinica Chimica Acta, 508, 254-266. https://doi.org/10.1016/j.cca.2020.05.044

Marelli, S., Castelnuovo, A., Somma, A., Castronovo, V., Mombelli, S., \& Bottoni, D. et al. (2020). Impact of COVID-19 lockdown on sleep quality in university students and administration staff. Journal Of Neurology. https://doi.org/10.1007/s00415-02010056-6

Mollayeva, T., Thurairajah, P., Burton, K., Mollayeva, S., Shapiro, C., \& Colantonio, A. (2016). The Pittsburgh sleep quality index as a screening tool for sleep dysfunction in clinical and non-clinical samples: A systematic review and meta-analysis. Sleep Medicine Reviews, 25, 52-73. https://doi.org/10.1016/j.smrv.2015.01.009

Morin, C., \& Carrier, J. (2020). The acute effects of the COVID-19 pandemic on insomnia and psychological symptoms. Sleep Medicine. https://doi.org/10.1016/j.sleep.2020.06.005

Shi, L., Lu, Z., Que, J., Huang, X., Liu, L., \& Ran, M. et al. (2020). Prevalence of and Risk Factors Associated With Mental Health Symptoms Among the General Population in China During the Coronavirus Disease 2019 Pandemic. JAMA Network Open, 3(7), e2014053. https://doi.org/10.1001/jamanetworkopen.2020.14053

Sinha, S. (2016). Trauma-induced insomnia: A novel model for trauma and sleep research. Sleep Medicine Reviews, 25, 74-83. https://doi.org/10.1016/j.smrv.2015.01.008

Voitsidis, P., Gliatas, I., Bairachtari, V., Papadopoulou, K., Papageorgiou, G., \& Parlapani, E. et al. (2020). Insomnia during the COVID-19 pandemic in a Greek population. Psychiatry Research, 289, 113076. https://doi.org/10.1016/j.psychres.2020.113076

Wang, C., Pan, R., Wan, X., Tan, Y., Xu, L., Ho, C., \& Ho, R. (2020). Immediate Psychological Responses and Associated Factors during the Initial Stage of the 2019 Coronavirus Disease (COVID-19) Epidemic among the General Population in China. 
International Journal Of Environmental Research And Public Health, 17(5), 1729. https://doi.org/10.3390/ijerph17051729

Wang, D., Hu, B., Hu, C., Zhu, F., Liu, X., \& Zhang, J. et al. (2020). Clinical Characteristics of 138 Hospitalized Patients With 2019 Novel Coronavirus-Infected Pneumonia in Wuhan, China. JAMA, 323(11), 1061. https://doi.org/10.1001/jama.2020.1585

WHO. (2020). Diagnostic testing for SARS-CoV-2. Who.int. Retrieved 30 October 2020, from https://www.who.int/publications/i/item/diagnostic-testing-for-sars-cov-2.

WHO. (2020). Coronavirus Disease (COVID-19) Dashboard. Covid19.who.int. Retrieved 31 October 2020, from https://covid19.who.int/.

Yang, L., Yu, Z., Xu, Y., Liu, W., Liu, L., \& Mao, H. (2020). Mental status of patients with chronic insomnia in China during COVID-19 epidemic. International Journal of Social Psychiatry, 66(8), 821-826. https://doi.org/10.1177/0020764020937716 